\title{
W sprawie polityczności polskiej humanistyki
}

Michał Kuziak

TEKSTY DRUGIE 2017, NR 1, S. 253-261

DOI: $10.18318 /$ td.2017.1.21

C

zy polska humanistyka - dodam najnowsza - jest polityczna? Zdroworozsądkowa odpowiedź powinna brzmieć: „tak i nie”, choć to zbyt proste rozwiązanie, domagające się rozwinięcia. „Nie”, ponieważ w ten sposób często - ciągle częściej niż przeciwnie - głoszą sami humaniści, podkreślający, że wartością jest „neutralność” i „obiektywizm”.,Nie”, ponieważ, i to jest o wiele poważniejszy argument, polscy humaniści rzadko świadomie zajmują w dyskursie pozycję polityczną.

Określenie „polityczny” stało się przy tym w polskiej humanistyce czymś podejrzanym. Ryszard Nycz we wprowadzeniu do „Tekstów Drugich” poświęconych "historii ratowniczej" nie używa ani razu słowa „polityka”, choć kontekst rozważań aż prosi się o to; Ewa Domańska używa je w zawartym w tym numerze pisma artykule projektującym ową historię raz... ${ }^{1}$ Wspomniana podejrzliwość zdaje się starsza niż rok 1989, na który wskazuje Przemysław Czapliński we wstępie do Polityki literatury, pisząc o niechęci twórców i krytyków do politycznych

1 Zob. E. Domańska Historia ratownicza, "Teksty Drugie” 2014 nr 5, s. 19.
Michał Kuziak - dr hab., profesor UW (Zakład Komparatystyki ILP). Autor książek poświęconych Mickiewiczowi (m.in. Inny Mickiewicz, 2013) i Słowackiemu (Fragmenty o Słowackim, 2001), retoryce (Jak mówić, rozmawiać, przemawiać?, kolejne wydania od 2005), a także ponad stu artykułów dotyczących literatury romantycznej i współczesnej oraz teorii literatury i komparatystyki literackiej. Redaktor wielu książek. W kadencji 2015-2018 członek Komitetu Nauk o Literaturze PAN. Kontakt: michakuziak@wp.pl 
koneksji literatury. Niechęć humanistów do polityki wywodzi się zapewne jeszcze z PRL-u, ma też szerszy XX-wieczny europejski kontekst. Wspiera ową niechęć dostrzeżone przez Czaplińskiego już w latach 90. przekonanie o postpolityczności czasów współczesnych, spełniających demokratyczną i neoliberalną utopię ${ }^{2}$. Dodam też - nieporadzenie sobie z wyzwaniami i zagrożeniami owych czasów, z ich nastawieniem do kultury, nauki i edukacji. To dopiero ostatnio pojawiają się poświęcone tej kwestii publikacje. Ciągle wszakże brakuje nam książki na miarę Nie dla zysku. Dlaczego demokracja potrzebuje humanistów Marthy C. Nussbaum, sytuującej humanistykę w perspektywie współczesnej ekonomii i polityki, dziejących się na naszych oczach procesów przekształcania się świata ${ }^{3}$.

Odpowiedź na pytanie o polityczność polskiej humanistyki może brzmieć „tak", bowiem, wbrew deklarowanej „neutralności” i „obiektywizmowi” oraz wymazywaniu kontekstu politycznego, wypowiedź humanisty niejako siłą rzeczy staje się polityczna. I to nie tylko dzięki kontekstowi, w którym się pojawia (m.in. za sprawą podejmowanych zagadnień). Wypowiedź taka zawsze wyrasta z jakiejś polityki, choć niejednokrotnie genealogia ta niejako się znaturalizowała i stała się niewidoczna, co zresztą również stanowi fenomen polityczny, konserwując status quo. Nie ukrywam przy tym, że w moim przekonaniu wspomniana naturalizacja jest zjawiskiem szkodzącym: zarówno humanistyce, jak i światu, z którym ta powinna istnieć w relacjach, odpowiadając na jego wyzwania; świadczy przy tym o zignorowaniu lekcji wynikającej choćby z ustaleń Michela Foucaulta.

I w końcu „tak", bowiem od pewnego czasu - myślę o ostatnich kilkunastu latach - pojawiają się w polskiej humanistyce głosy, które wpisują się bądź chcą się wpisywać w wymiar polityki. Przykładem może być choćby deklaracja otwierająca książkę Joanny Krakowskiej PRL. Przedstawienia i zarazem serię Teatr publiczny. Przedstawienia 1765-2015. Autorka pisze: „Zapomnijmy o bezinteresowności. Patrzenie w przeszłość nie jest zajęciem dla obiektywnych obserwatorów, obojętnych arbitrów i asekurantów. Neutralność i deklarowany brak uprzedzeń? To chyba nieporozumienie, skoro mamy mówić o historii. Bezstronność? Żart"4.

2 Zob. P. Czapliński Polityka literatury, czyli pokazywanie języka, w: Polityka literatury, red. P. Czapliński, Wydawnictwo Krytyki Politycznej, Warszawa 2009, s. 8 i n.

3 Zob. M.C. Nussbaum Nie dla zysku. Dlaczego demokracja potrzebuje humanistów, przeł. Ł. Pawłowski, przedm. J. Kuisz, Kultura Liberalna, Warszawa 2016.

4 J. Krakowska PRL. Przedstawienia, PIW, Wydawnictwo Instytutu Teatralnego, Warszawa 2016, s. 7. 
Pytając o polityczność humanistyki, szukam projektów politycznych wyrastających z humanistyki. Nie zajmują mnie przy tym wypowiedzi jedynie tematyzujące politykę. Próbując dookreślić znaczenie „polityczności” na potrzeby dalszych rozważań, wstępnie przyjmuję, że chodzi o chęć oddziaływania na czytelnika - na jego przekonania i postawy związane z szeroko pojętym życiem wspólnotowym. A więc to pragnienie sprawstwa, o którym coraz częściej mówi się we współczesnej polskiej humanistyce, jest kluczowe dla wyznaczenia pola humanistyki politycznej.

Wypada też zwrócić tu uwagę na autorów, którzy wprawdzie bezpośrednio nie zajmują pozycji politycznej, niemniej ich publikacje niejako siłą rzeczy okazują się głosem politycznym - czy lepiej: mogą okazać się takim głosem - w związku z podejmowanym tematem, aktualnym czy kontrowersyjnym. W polskiej humanistyce dotyczy to zwłaszcza problematyki żydowskiej, historii najnowszej po 1939 roku, a ostatnio okresu transformacji po 1989 roku$^{6}$. Być może wkrótce podobnie będzie z zagadnieniami generowanymi przez biopolitykę.

To właśnie wspomniane wyżej głosy będą mnie tu zajmować szczególnie, choć mam przekonanie, odmiennie niż Anna Burzyńska poświęcająca tej kwestii dygresję w książce Dekonstrukcja, polityka i performatyka ${ }^{7}$, że jednak zwrot polityczny polskiej humanistyki, okazał się, jak dotąd, dość nieśmiały. Trzeba przy tym zauważyć, że przywołane przez autorkę książki - Igora Stokfiszewskiego Zwrot polityczny, Pawła Mościckiego Polityka teatru czy tomik Krytyki Politycznej Polityka literatury ${ }^{8}$ - nie tyle zawierają projekt i realizację politycznej humanistyki (wyjątkiem jest może w pewnej mierze książka Stokfiszewskiego, przynajmniej utrzymane w profetycznym tonie wprowadzenie do niej), ile przedstawiają zjawiska polityczne w kulturze i sztuce, szukając nowej, innej od dotychczasowych, formuły ich polityczności. Wydaje się, że

5 Zob. np. P. Dybel, Sz. Wróbel Granice polityczności, Aletheia, Warszawa 2008 (choć w tym przypadku wypada także odnotować skomplikowanie sytuacji: autorzy - w tym przypadku Paweł Dybel - pozwalają sobie na wykroczenie poza opis podjętej problematyki i zajęcie stanowiska politycznego w przypisach czy w aneksie książki).

6 Książki poświęcone tej kwestii mogą odznaczać się także wyraźnie zarysowaną perspektywą polityczną związaną z udziałem w debacie nad przedstawianym zjawiskiem; przykładem może być książka P. Dybla Dylematy demokracji. Kontekst polski, Universitas, Kraków 2015.

7 Zob. A. Burzyńska Dekonstrukcja, polityka i performatyka, Universitas, Kraków 2013, s. 223 i n.

8 Zob. P. Mościcki Polityka teatru. Eseje o sztuce angażującej, Wydawnictwo Krytyki Politycznej, Warszawa 2008; I. Stokfiszewski Zwrot polityczny, Wydawnictwo Krytyki Politycznej, Warszawa 2009. 
rację ma Stokfiszewski, kiedy zauważa, że to krytyka artystyczna okazuje się bardziej polityczna niż akademicka humanistyka.

Niejako siłą rzeczy trudno tu pominąć krytyki subwersywne, naznaczone implicite politycznością, zwrócone w kierunku problematyki mniejszości i wykluczenia; w Polsce widoczne zwłaszcza pod postacią krytyki genderowej, szczególnie w wariancie feministycznym, a ostatnio także LGBTQ oraz postkolonialnej (postzależnościowej), o której już wspominałem. Można też dostrzec, ciągle jeszcze nieśmiały, głos neo/marksistów; przykładem inspiracji myślą Marksa mogą być prace Jana Sowy, do których jeszcze powrócę.

Zwłaszcza w odniesieniu do krytyki genderowej wypada przynajmniej odnotować częste zaangażowanie publicystyczne autorek i autorów, interwencyjność ich wystąpień. W znamienny sposób Inga Iwasiów w Gender dla średnio zaawansowanych, odsłaniając swoją pozycję intelektualną i polityczną, powiada w jednym $\mathrm{z}$ fragmentów wywodu krytykującego ograniczanie się do fetyszy dyskursu humanistycznego (chodzi o kategorię „Innego”): „Trzeba wykonać krok od teorii do etyki; od spekulacji do świadomości. Od deklaracji pluralizmu, społeczeństwa otwartego - do jego praktykowania"10.

Nie przypadkiem Michał Paweł Markowski w trakcie ostatniego Światowego Kongresu Polonistów (Katowice 2016) przedstawił swój projekt humanistyki politycznej, nawiązując do zaproponowanej kiedyś przez Marię Janion formuły humanistyki jako poznania i terapii ${ }^{11}$. Bez wątpienia autorka ta jest centralną postacią polskiej humanistyki politycznej, a na dodatek zajmuje się fundamentalnym problemem polskiej kultury, jakim jest romantyzm. W zasadzie wszystkie związane z ową humanistyką wątki, o których będę pisał, pojawiają się w twórczości Janion. Wystarczy tu przywołać choćby Niesamowitą Stowiańszczyznę $e^{12}$, która jest również o tyle znamiennym przykładem, że jej recepcja, pomijająca fakt, że książka, jak deklaruje badaczka, jest projektem, opowieścią, a skupiająca się głównie na weryfikacji ustaleń faktograficznych, ujawnia nasz problem z humanistyką polityczną, ciągle traktowaną jako zjawisko dość ekscentryczne i w związku z tym niezrozumiałe.

9 Zob. serię książek wydawanych w Universitasie przez Centrum Badań Postzależnościowych.

10

I. Iwasiów Gender dla średnio zaawansowanych. Wykłady szczecińskie, W.A.B., Warszawa 2008, S. 18.

Zob. M. Janion Humanistyka: poznanie i terapia, PIW, Warszawa 1974.

Zob. M. Janion Niesamowita Słowiańszczyzna: fantazmaty literatury, Wydawnictwo Literackie, Kraków 2006. 
W 2014 roku na łamach „Tekstów Drugich” rozegrał się spór Sowy z Markowskim, bodaj pierwsza we współczesnej polskiej humanistyce polemika o jej polityczność. Osią kontrowersji stała się przyjęta przez autora Polityki wrażliwości, mająca ją określać, wywiedziona z niemieckiego romantyzmu koncepcja Bildung oraz praktyka dekonstrukcyjna ${ }^{13}$.Zdaniem autora to właśnie polityczny charakter (nie)dyscypliny, jaką jest humanistyka - a nie jej autonomia i budowany wokół niej profesjonalizm - zdolność do wymyślania i nadawania sensu sferze publicznej, jej ciągłej rekonfiguracji oraz transgresji „ja”, ma legitymizować humanistykę; polityczny nie wiąże się przy tym z doraźną polityką, oznacza lekcję wielości i nieostateczności słowników finalnych, otwarcia na możliwą inność.

Sowa zarzuca książce Markowskiego brak słuchu społecznego i uleganie prywatnej idiosynkrazji, wiodące $\mathrm{w}$ istocie do ustanowienia dyskursu egzystencjalnego, skupionego w rzeczywistości na estetyce pojedynczego istnienia, pomijającego wspólnotowośćc ${ }^{14}$. Krytykowany badacz ma hołdować fetyszowi tekstualności i związanej z nią przyjemności. Mówiąc językiem Lacana, Sowa stwierdza, że autor Polityki wrażliwości ucieka od Realnego, którym jest rzeczywistość ekonomiczna i społeczna, a proklamując pochwałę wielości i różnorodności dyskursów, wpisuje się w ekonomię neoliberalizmu ze wszystkimi jej fatalnymi konsekwencjami. Sam krytyk wyznacza humanistyce specyficzny cel dezalienacyjny, wiodący do odzyskania przez podmiot poczucia sprawstwa. Wydaje się, że zarzucając Markowskiemu ignorowanie problematyki wspólnotowej, Sowa w rzeczywistości zarzuca mu jej odmienne od własnego rozumienie, podobnie jest z innymi aspektami sporu. „Polityka wrażliwości" zdaje się stanowić projekt liberalny, krytyka Sowy jest z kolei umocowana w myśleniu lewicowym, starającym się odciąć od lewicy liberalnej.

Polityczność polskiej humanistyki najczęściej manifestuje się w związku z formułą, którą za Kingą Dunin określiłbym mianem „czytając Polskę"15. Myślę tu o, często umocowanych w różnych językach krytycznych, lekturach zakładających, że Polska/polskość stanowi znaczący tekst, który wymaga wykorzystania odpowiedniej hermeneutyki, by odsłonić i zrozumieć to znaczenie.

13 Zob. M.P. Markowski Polityka wrażliwości. Wprowadzenie do humanistyki, Universitas, Kraków 2013.

Zob. J. Sowa Humanistyka płaskiego świata, "Teksty Drugie” $2014 \mathrm{nr} 1$.

15 K. Dunin Czytając Polskę. Literatura polska po rok 1989 wobec dylematów nowoczesności, W.A.B., Warszawa 2004. 
"Czytanie Polski” może realizować się na płaszczyźnie literaturoznawczej (np. wspomniana Dunin czy Czapliński ${ }^{16}$, również Jarosław Marek Rymkiewicz ${ }^{17}$ ), co wiąże się z traktowaniem literatury nie tyle jako wymiaru operacji językowych, ile jako wielorako splecionej z rzeczywistością i szczególnie wyczulonej na jej procesy, również jako swego rodzaju laboratorium przyszłości; postępują tak zresztą nie tylko literaturoznawcy, o czym świadczą książki Dariusza Gawina czy Szymona Wróbla ${ }^{18}$. „Lektura Polski” najczęściej wiąże się z problematyką tożsamościową, z odsłanianiem kodu polskości. Żywi się wizją pracy nad świadomością wspólnoty. Spojrzenie w mniej lub bardziej oddaloną przeszłość okazuje się spojrzeniem w lustro, dzięki któremu możemy lepiej zrozumieć swoją współczesność.

Takie czytanie widoczne jest także $\mathrm{u}$ historyków (np. Wielka trwoga Marcina Zaremby ${ }^{19}$ ), antropologów (np. Okrzyki pogromowe Joanny Tokarskiej- Bakir $^{20}$ ), socjologów (np. Fantomowe ciało króla Jana Sowy ${ }^{21}$ ), filozofów (np. Prześniona rewolucja Andrzeja Ledera ${ }^{22}$ ), teatrologów (np. Teatra polskie. Rok katastrofy Dariusza Kosińskiego ${ }^{23}$ ), kulturoznawców (np. Powstanie umartych. Historia pamięci 1944-2014 Marcina Napiórkowskiego ${ }^{24}$ ). Oczywiście enumerację tę można by kontynuować. Wymienieni autorzy nieliteraturoznawcy czytają Polskę w związku z historią, uruchamiając różne języki interpretacyjne, często zresztą korzystając z metod różnych dyscyplin czy zajmując się polem tradycyjnie związanym z inną dyscypliną niż macierzysta piszącego.

16 Zob. m.in. ostatnią książkę P. Czaplińskiego Poruszona mapa, Wydawnictwo Literackie, Kraków 2016. Zob. J.M. Rymkiewicz Samuel Zborowski, Sic!, Warszawa 2010.

Zob. D. Gawin Polska wieczny romans. O zwiqzzkach literatury i polityki wXX wieku, Ośrodek Myśli Politycznej, Warszawa 2005; Sz. Wróbel Polska pozycja depresyjna: od Gombrowicza do Mrożka, Universitas, Kraków 2015.

Zob. M. Zaremba Wielka trwoga. Polska 1944-1947. Ludowa reakcja na kryzys, Znak, Kraków 2012.

Zob. J. Tokarska-Bakir Okrzyki pogromowe: szkice z antropologii historycznej Polski lat 1939-1946, Wydawnictwo Czarne, Wołowiec 2012.

21 Zob. J. Sowa Fantomowe ciało króla: peryferyjne zmagania z nowoczesną forma, Universitas, Kraków 2011. Zob. A. Leder Prześniona rewolucja. Ćwiczenie z logiki historycznej, Wydawnictwo Krytyki Politycznej, Warszawa 2014.

3 Zob. D. Kosiński Teatra polskie. Rok katastrofy, Znak, Warszawa-Kraków 2013.

Zob. M. Napiórkowski Powstanie umarłych. Historia pamięci 1944-2014, Wydawnictwo Krytyki Politycznej, Warszawa 2016. 
Przykładem takiej praktyki może być książka Sowy, łącząca dyskursy ekonomii, psychoanalizy, historiografii i politologii. Takie postępowanie zdaje się odsłaniać zarówno skomplikowanie podejmowanych zagadnień, jak i przekonanie, że to właśnie ich logika - a nie tylko logika dyscypliny - powinna wyznaczać horyzont interpretacji.

Wypada przy tym zauważyć, że to zwłaszcza w przypadku „czytania Polski” mamy do czynienia ze wspomnianym przeze mnie wyżej zjawiskiem zajmowania pozycji politycznej nie tylko w sposób zadeklarowany, ale też niejako siłą rzeczy, przez podjęcie politycznego tematu. Wymienieni autorzy obudowują swój wywód precyzyjnie sformułowaną metodą (Tokarska-Bakir); eksponują posiadane archiwum (Zaremba); deklarują pragnienie obiektywizmu (Kosiński). Wyraźnie podkreślają w ten sposób, że chcą pozostać po stronie dyskursu naukowej humanistyki umocowanej w kategorii profesjonalizmu. Eksponuję to zjawisko, gdyż świadczy ono o tym, że nie musi istnieć opozycja między nią a humanistyką polityczną; podobnie rzecz wygląda w książkach formułujących projekty.

W ostatnich latach można zaobserwować popularność formuły eksponującej alternatywną inwencyjność. Pojawiła się ona np. w tytułach i rozważaniach tak rozmaitych i, wypada dodać, zantagonizowanych autorów (znów w związku z konfliktem liberalno-lewicowym), jak Agata Bielik-Robson czy Jan Sowa; można tu jeszcze wspomnieć o Andrzeju Szahaju, biorącym udział w sporze o kształt polskiego kapitalizmu ${ }^{25}$. Tendencja ta zdaje się zapowiadać odchodzenie od perspektywy wyznaczonej przez języki krytyczne i dekonstrukcję ku próbie konstruowania swego rodzaju subtelnych utopii, których twórcy jednak mają na uwadze problematyczność statusu prawodawcy.

Przyjrzyjmy się dwojgu pierwszym spośród wymienionych autorów. Bielik-Robson wykorzystuje romantyzm w polemice z racjonalną nowoczesnością i jej wizją podmiotu ${ }^{26}$, a także z postmodernizmem dekonstruującym taki podmiot. Projektuje „inną nowoczesność", umocowaną w romantyzmie, dającą szansę na odbudowę podmiotowości, mocnej nie dzięki racjonalności, a dzięki wyobraźni i uczuciom. Odbudowa taka wiąże się także ze stworzeniem nowej wspólnoty: liberalnej z ducha, otwartej na indywidualną wolność, działanie, krytyczność, różnice i prawo do dobrego, szczęśliwego życia ${ }^{27}$.

25 Zob. A. Szahaj Inny kapitalizm jest możliwy, Książka i Prasa, Warszawa 2015.

26 Zob. A. Bielik-Robson Inna nowoczesność. Pytania o współczesną formułę duchowości, Universitas, Kraków 2000.

27 Zob. A. Bielik-Robson Romantyzm, niedokończony projekt, Universitas, Kraków 2008, s. 15 i n. 
Warto tu podkreślić ponadto widoczną u autorki próbę zastąpienia tradycji polskiego romantyzmu - jak się okazuje ciągle istotnej w naszym życiu politycznym - romantyzmem angielskim.

Z kolei Sowa w książce Inna Rzeczpospolita jest możliwa przez „inność” rozumie zarówno własną, odrębną od zachodniej neoliberalnej, tradycję polityczną związaną z dziedzictwem pierwszej Solidarności ${ }^{28}$, jak i wymyślanie projektów utopijnych, wyrastających z lewicowej perspektywy demokracji radykalnej. Argumentem autora, biorącego udział w sporze o kształt polskiej polityki, jest historia i przynajmniej częściowa realizacja dotychczasowych projektów emancypacyjnych, a także przyszłość - nasz obowiązek wobec niej. Stąd postulat ćwiczenia wyobraźni, dopełniającego pracę języków krytycznych, któremu towarzyszy niezgoda na es muss sein historycznego determinizmu i pragnienie odzyskania poczucia sprawstwa.

Obraz polskiej humanistyki politycznej pozostałby niepełny bez wspomnienia o formule „historii ratowniczej”. Proponuje ją Ewa Domańska w swoim work in progress - podobny charakter mają zresztą także pozostałe przywoływane tu przeze mnie projekty - powstającym po książce Historia egzystencjalna. Krytyczne studium narratywizmu i humanistyki zaangażowanej, w której to autorka m.in. postulowała powstanie mocnego sprawczego podmiotu i wzmocnienie wspólnoty, realizującej ideę dobra wspólnego ${ }^{29}$. W projekcie historii ratowniczej chodzi Domańskiej o specyficznie rozumianą historię, która jest zwrócona ku przyszłości. Pozwala na przepracowanie przeszłości i przynoszonych przez nią konfliktów oraz traum, na kształtowanie się podmiotu i zbiorowości, stworzenie archiwów dających możliwość konstruowania projektów i scenariuszy przyszłości. W ten sposób ma zostać poszerzony wymiar partycypacji - zarówno w nauce, jak i w polityce ${ }^{30}$.

Pointując, napiszę, że w moim przekonaniu zadaniem i wyzwaniem dla humanistyki powinno okazać się stworzenie przestrzeni debaty, sporu, negocjacji - tak potrzebnych w demokratycznym państwie. Takim zadaniem jest

Zob. J. Sowa Inna Rzeczpospolita jest możliwa, W.A.B., Warszawa 2015. Co znamienne, autor przekłada w tej książce na język publicystyki tezy, które sformułował w książkach respektujących reguły pisarstwa naukowego - wspomnianym Fantomowym ciele króla oraz Ciesz się późny wnuku! Kolonializm, globalizacja i demokracja radykalna (Ha!art, Kraków 2008). Podobnie postępuje w swoich książkach na temat neoliberalizmu A. Szahaj.

E. Domańska Historia egzystencjalna. Krytyczne studium narratywizmu i humanistyki zaangażowanej, PWN, Warszawa 2012, s. 138. 
zaproponowanie języków pozwalających fortunnie wypowiedzieć roszczenia i zdefiniować interesy, objaśniać zmieniający się świat i operować krytyką, a także projektować utopie. Chcę przy tym podkreślić, że - jak można było obserwować na przykładzie przywoływanych przeze mnie prac - polityczność humanistyki nie musi wykluczać jej profesjonalizacji (choć ta może być rozumiana odmiennie niż dotychczas), bez wątpienia chroniącej przed zbytnią instrumentalizacją.

\section{Abstract}

\section{Michał Kuziak}

UNIVERSITY OF WARSAW

The Political Nature of the Humanities in Poland

How political are the humanities in Poland today? Kuziak examines the possibilities and limitations of this question in the discourse of humanities scholars. He focuses on the formula'reading Poland' that reappears in these discourses, but also on projects of possible otherness and rescue history. The humanities' political nature is shown to legitimize scholarly discourses in that it connects them to history and society.

\section{Keywords}

engaged humanities, 'reading Poland', utopia, critical theories, rescue history 